\title{
A Six-phase Model to Simulate the Contamination by Non-conservative Radionuclides of Sediments, Soils and Plants in a Marsh Area. Application to the Odiel Marsh in Southwest Spain
}

\author{
R. Periáñez \& A. Martínez-Aguirre \\ Dpto Física Aplicada, E.U. Ingeniería Técnica Agrícola, Universidad de Sevilla, Ctra \\ Utrera km, 1, 41013-Seville, Spain
}

(Rcceived 28 Junc 1996; acceptcd 11 October 1996)

\section{ABSTRACT}

A numerical model to simulate the dispersion of non-conservative radionuclides in an estuarine system that surrounds a marsh area has been developed. The model includes six phases: water, two types of suspended particles (natural particles in the estuary and contaminated particles released from the source of contamination), bottom sediments, soils and plants (Spartina densiflora). Radionuclides in water and suspended matter are transported along the river by advection and diffusion processes, ionic exchanges between water and the solid phases and deposition of suspended particles on bottom sediments also occur. Radionuclides are incorporated in soils in the marsh during the time that they are covered by water. Finally, they are transferred from the soil to the plants. All these processes are represented by a set of partial differential equations. A spatial and temporal discretization is carried out and a finite differences scheme is adopted to solve them. The model must run over long time scales (years) if model results are to be compared with experimental measurements in the estuary and marsh. Thus, residual water circulation is used to solve the advective-diffusive terms in the equations. Ionic exchanges are described by kinetic transfer coefficients and the transfer of radionuclides from soils to plants by concentration ratios, $\mathrm{C}_{R}$. The model is applied to the Odiel marsh. The Odiel river forms an estuarine system (which surrounds a large marsh area) in which a phosphate fertilizerprocessing complex releases its waste. The model yields good results in 
predicting ${ }^{238} \mathrm{U},{ }^{210} \mathrm{Po}$ and ${ }^{232} \mathrm{Th}$ concentrations in bottom sediments, soils and plants collected from the river and marsh. A predictive study, concerning the process of cleaning of the marsh, has also been carried out. (C) 1997 Elsevier Science Ltd.

\section{INTRODUCTION}

Mathematical models, developed to simulate the dispersion of radionuclides in aquatic systems, have been improved over the last few years. The first models successfully simulated the dispersion of dissolved radionuclides in the sea (Prandle, 1984). Later, the exchange of radionuclides between water and the solid phases (suspended matter and bottom sediments) was included. In these models (Howorth \& Eggleton, 1988; Kershaw et al., 1988; Abril \& García-León, 1993a), ionic exchanges between water and the solid phases were described in terms of distribution coefficients, $k_{\mathrm{d}}$, since the time steps used required that ionic exchanges reach equilibrium in each time step.

Recently, one of the authors developed a model in which the ionic exchanges were described in terms of kinetic transfer coefficients (Periáñez et al., 1996a). Thus, the model can be used, even in conditions of disequilibrium for ionic exchanges. This allows the use of large spatial and temporal resolutions in the model. Such a model was applied to simulate the dispersion of ${ }^{226} \mathrm{Ra}$ in the Odiel river, a tidal estuary in which a phosphate fertilizer complex releases its waste. It was possible to reproduce not only the spatial and temporal variations of ${ }^{226} \mathrm{Ra}$ concentrations in water and suspended matter due to tidal oscillations, but also the variability in distribution coefficients (Periàñez et al., 1996b).

Now, a model to simulate the dispersion of non-conservative radionuclides in a marsh area has been developed. The model includes the transfer of radionuclides between water, suspended matter and bottom sediments following the description by Periáñez et al. (1996a). The transfer of such radionuclides to plants growing in the marsh has also been included in the model. Thus, this work represents a new achievement in radioecological models. The studied plants grow in sites that are flooded during part of the tidal cycle (these sites will be denoted as soils to distinguish them from the bottom sediments that are always under the water). Thus, the transfer of radionuclides to these soils must be implemented in the model. Then, the transfer of radionuclides from the soil to the plant is included. This transfer is described by the concentration ratio, $C_{\mathrm{R}}$, which is defined as the ratio between the concentration of an element in the plant and that in its substrate. 
The model is applied to the Odiel marsh, in southwest Spain. The Odiel river forms, at its lowest reaches, a tidal estuary that discharges into the Atlantic Ocean. This estuary surrounds a large marsh area. A phosphate fertilizer processing complex releases part of its wastes to the Odiel river. It is well known (Van der Heijde et al., 1988; Laiche \& Scott, 1991) that such wastes contain significant amounts of $\mathrm{U}, \mathrm{Th}, \mathrm{Ra}$ and their daughters. Indeed, anomalously high concentrations of ${ }^{226} \mathrm{Ra}$, ${ }^{238} \mathrm{U},{ }^{210} \mathrm{Po}$ and ${ }^{232} \mathrm{Th}$ have been detected in water, suspended matter, bottom sediment, soil and plant (Spartina densiflora and Spartina maritima) samples collected from the Odiel river and marsh (Periáñez \& García-León, 1993; Periáñez et al., 1994b; Martínez-Aguirre et al., 1994a, $b$; Martínez-Aguirre \& García-León, 1997; Martínez-Aguirre et $a l$., in press). The model will be used to simulate the dispersion of ${ }^{238} \mathrm{U}$, ${ }^{210} \mathrm{Po}$ and ${ }^{232} \mathrm{Th}$ along the estuary and the transfer of such radionuclides to bottom sediments in the river and to soils and plants (Spartina densiflora) in the marsh area. Thus, it will be demonstrated that radionuclides released from the fertilizer complex reach the marsh by means of water movements: the enhanced activity levels observed in soils and plants in the marsh are due to the operation of the fertilizer complex. Some predictive studies concerning the process of cleaning of the marsh have also been carried out.

The model is described in the next section. Next, model results are presented and discussed.

\section{MODEL DESCRIPTION}

Radionuclides are released into the river in dissolved and particulate form and are transported along the river by advection and diffusion processes. Thus, water circulation must be known to solve the advective-diffusive equation. Ionic exchanges between water and the solid phase (suspended matter and bottom sediments) also take place. The model includes two kinds of suspended matter particles: contaminated particles released from the fertilizer complex and natural suspended matter particles in the river. Deposition and resuspension of both types of suspended particles occurs, which lead to an exchange of radionuclides between suspended matter and bottom sediments. Radionuclides can be incorporated in soils (during the part of the tidal cycle when they are covered by water) by the same processes in which they are incorporated in bottom sediments: deposition of suspended particles and ionic exchanges with water. All these processes are described by a set of partial differential equations. To solve them, a spatial and 
temporal discretization of the equations is carried out, and a finite difference scheme is adopted, using forward differences in time and centred differences in space. Thus, the study area is divided into a number of grid cells or compartments. Several phases are present inside each grid cell: water, suspended matter and bottom sediments, or, for cells in the marsh area, soil and plants.

The incorporation of radionuclides in soils and plants has been taking place over the operational period of the fertilizer complex (30 years ago). 'Thus, if we want to compare the model results with experimental measurements, the model should run for long time scales. Instead of solving the hydrodynamic equations for each time step (Periáñez et al., 1996a) to obtain the water circulation, the model will work with residual (averaged) water circulation. This permits the use of larger time steps and, as a consequence, longer simulation periods.

\section{Water circulation}

The residual circulation at a point is obtained finding the average water velocity over a complete tidal cycle at such point. In Puerto Autónomo de Huelva (1989), these water velocities are measured at several points of the estuary for a medium tide situation. At points where there are no measurements, residual water velocity is calculated by taking into account that the stream flow of the river is the same in all sections (continuity equation). In Fig. 1 the residual water circulation for the modelled area is shown. It can be seen that residual water velocities are of the order of $10^{-2} \mathrm{~m} \mathrm{~s}^{-1}$, which is a typical value for residual flows (Elliott et al., 1992; Prandle et al., 1993).

Once the magnitude of the maximum residual velocity is known, model resolutions are selected so as to satisfy a stability condition (Prandle, 1974) and to minimize numerical dispersion (Periáñez et al., 1994a). These resolutions are $\Delta t=600 \mathrm{~s}$ and $\Delta x=\Delta y=250 \mathrm{~m}$. This spatial resolution leads to 1380 grid cells.

\section{Suspended matter dynamics}

The averaged suspended matter distribution over the whole study area must also be known to compute the ionic exchange of radionuclides between water and suspended matter. Suspended matter is transported along the river by advection and diffusion processes. The vertical movement of suspended matter is governed by deposition and resuspension terms, which are formulated in terms of critical deposition and resuspen- 


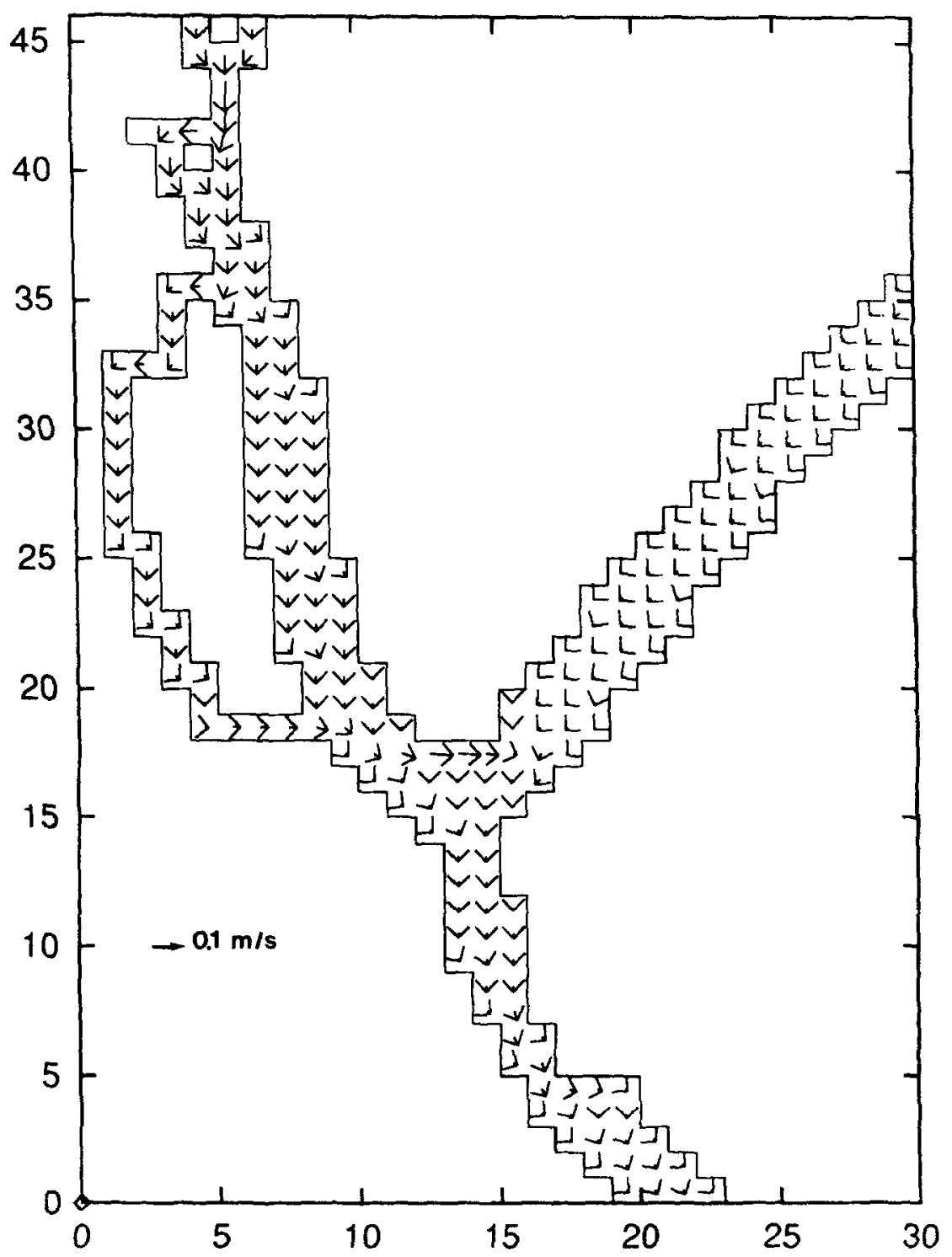

Fig. 1. Residual water circulation in the modelled area. Each unit in the $x$ and $y$-axis is equal to $250 \mathrm{~m}$.

sion velocities in such a way that there is deposition only if the water velocity is smaller than the critical deposition velocity. For larger values of the water velocity, deposition is hindered by water turbulence. On the other hand, there is resuspension only if the water velocity is larger than the critical resuspension velocity, otherwise there will not be enough 
energy to lift particles from the sediments. Details of the equations can be seen in Periáñez et al. (1996c).

The steady-state distribution of suspended matter obtained after a simulation period of 1 year is presented in Fig. 2. Suspended matter concentrations were measured along a tidal cycle (Periáñez et al., 1996c) at three points of estuary. The mean suspended matter concentration at each
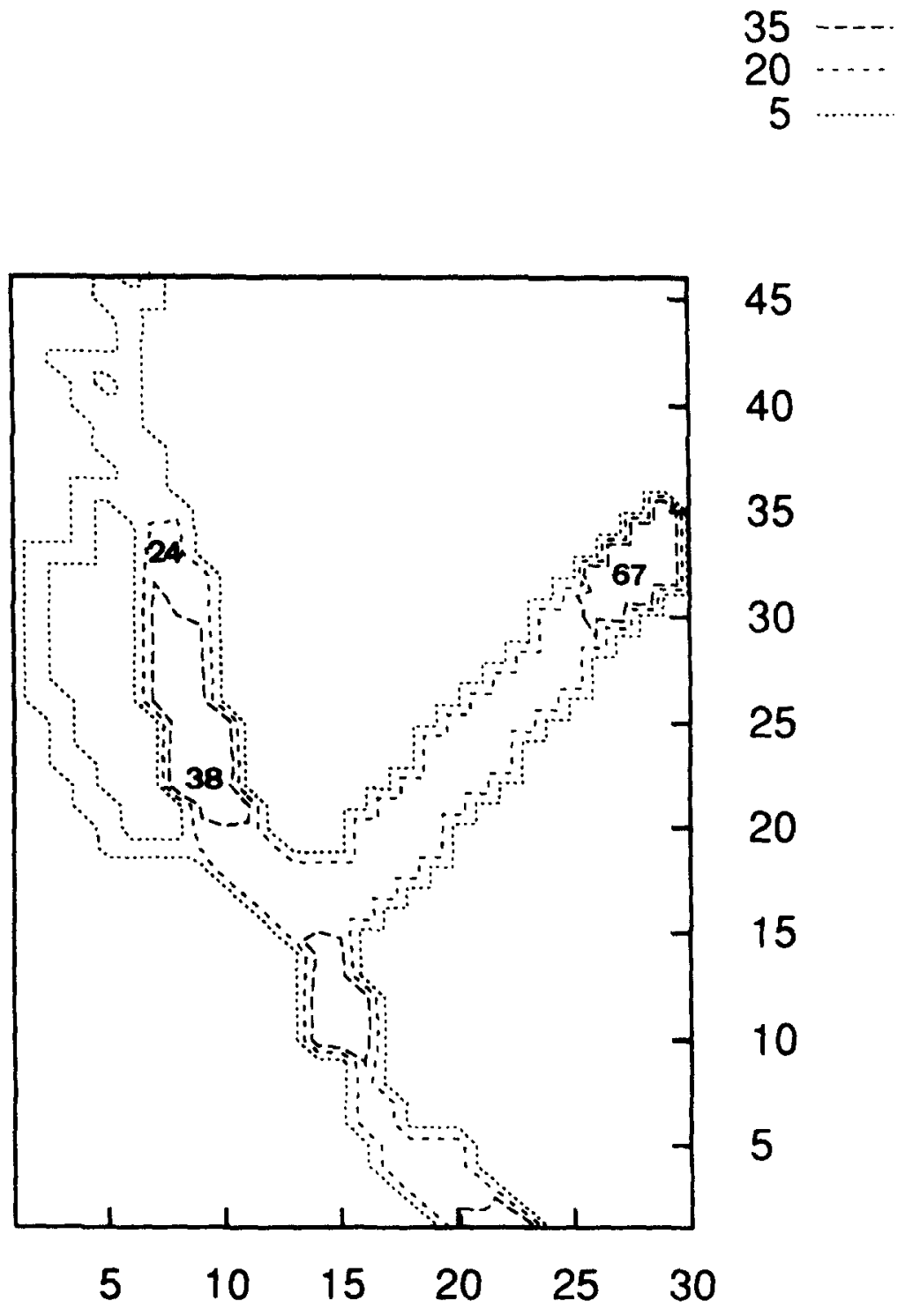

Fig. 2. Steady state distribution of suspended matter $\left(\mathrm{mg} \mathrm{l}^{-1}\right)$. Numbers inside the map are experimental measurements (mean values over a tidal cycle). 
point is also presented in Fig. 2. As can be seen, the model results are in agreement with the field measurements. The sedimentation rates (net balance between the deposition and resuspension terms) are then obtained from the steady state distribution of suspended matter for the whole study area. A net, although slow, sedimentation is produced over the whole study area since typical sedimentation rates are about $0.01 \mathrm{~g} \mathrm{~cm}^{-2}$ year $^{-1}$, a result in agreement with previous modelling work concerning part of the Odiel river (Periáñez et al., 1996c).

\section{Radionuclides dispersion}

Ionic exchanges are described in terms of kinetic transfer coefficients. Thus, the transfer from water to the solid phases (both kinds of suspended particles and bottom sediments) is governed by a coefficient $k_{1}$ and the inverse process by a coefficient $k_{2}$. The concept of exchange surface (surface of particles per water volume unit in the grid cell) is used to obtain an analytical expression for the coefficient $k_{1}$ (Periáñez et al., 1996a).

The equation whose solution gives the time evolution of specific activity in water $\left(C_{\mathrm{d}}\right.$, in $\left.\mathrm{Bq} \mathrm{m}^{-3}\right)$ is:

$$
\frac{\partial C_{\mathrm{d}}}{\partial t}=(\mathrm{adv}+\mathrm{dif})-k_{1} C_{\mathrm{d}}+k_{2} m C_{\mathrm{s}}+k_{2} m_{\mathrm{f}} C_{\mathrm{f}}+k_{2} \frac{a_{\mathrm{s}} L \rho_{\mathrm{m}} f \psi}{H} \times 10^{3} .
$$

The time derivative is interpreted as in a forward finite difference scheme. adv + dif means advective plus diffusive transport of dissolved radionuclides from one grid cell to another. This transport is computed by solving the advective-diffusive dispersion equation previously written in finite differences (Periáñez et al., 1994a). The second term is the transfer of radionuclides from water to the solid phase. The transfer coefficient $k_{1}$ is written as (Periáñez et al., 1996a):

$$
k_{1}=\chi_{1}\left(\frac{3}{\rho R}\left(m+m_{\mathrm{f}}\right)+\frac{3 L f \psi}{R H}\right)
$$

where $\rho$ is the density of the suspended matter particles, $R$ their mean radius, $m$ the concentration of natural suspended matter particles in the water and $m_{\mathrm{f}}$ the concentration of particles discharged from the fertilizer complex (both are measured in $\mathrm{mgl}^{-1}$ ). $L$ is the mean depth to which the water penetrates the sediment, due to its porosity. $\psi$ is a geometrical accessibility factor that takes into account that not all the mass of the sediment is, due to geometrical reasons, in contact with water. $f$ gives the dry weight fraction of muds (particles with diameter $\phi<62.5 \mu \mathrm{m}$ ) in the sediment. Thus, $f$ gives the fraction of 'active' sediment (Benes et al., 
1994), that is, sediments capable of resuspension. $H$ is the water column height and $\chi_{1}$ is the exchange velocity (Periáñez et al., 1996a), which depends on the water conditions ( $\mathrm{pH}$, salinity, temperature).

The next two terms in eqn (1) describe the transfer of radionuclides from both kinds of suspended particles to the water. $C_{f}\left(\mathrm{~Bq} \mathrm{~g}^{-1}\right)$ is the specific activity in particles discharged from the fertilizer complex and $C_{\mathrm{s}}$ $\left(\mathrm{Bq} \mathrm{g}^{-1}\right)$ is the specific activity in natural suspended particles. The transfer coefficient $k_{2}$ does not depend on the suspended matter concentration (Periáñez et al., 1996a).

The last term is the transfer of radionuclides from active bottom sediments to water. $a_{\mathrm{s}}$ is the specific activity $\left(\mathrm{Bq} \mathrm{g}^{-1}\right)$ in the active sediment and $\rho_{\mathrm{m}}$ is the bulk density of the sediment in $\mathrm{kg} \mathrm{m}^{-3}$.

The equation that gives the time evolution of specific activity in natural suspended matter particles is:

$$
\frac{\partial C_{\mathrm{s}}}{\partial t}=(\mathrm{adv}+\mathrm{dif})-\frac{w C_{\mathrm{s}}}{m H}+k_{1} \frac{C_{\mathrm{d}}}{m}-k_{2} C_{\mathrm{s}},
$$

where adv + dif means the advective plus diffusive transport of radionuclides in natural suspended matter along the river. The second term is the transfer of radionuclides to the sediment due to deposition of suspended particles, and $w$ is the sedimentation rate $\left(\mathrm{g} \mathrm{m}^{-2} \mathrm{~s}^{-1}\right)$. The third term is the transfer of radionuclides from water to natural suspended particles, where $k_{1}$ is given by:

$$
k_{1}=\chi_{1} \frac{3 m}{\rho R}
$$

The last term is the transfer of radionuclides from suspended particles to water.

Particles discharged from the fertilizer complex will be transported along the river by advection and diffusion processes and will be incorporated into bottom sediments by deposition. Thus, an equivalent equation to that described in 'Suspended matter dynamics' gives the concentration of particles discharged from the complex, $m_{\mathrm{f}}$, at each grid cell, as well as the sedimentation rate, $w_{f}$, for this type of particle.

The equation that gives the time evolution of specific activity in these particles, $C_{\mathrm{f}}$, is:

$$
\frac{\partial C_{\mathrm{f}}}{\partial t}=(\mathrm{adv}+\mathrm{dif})-\frac{w_{\mathrm{f}} C_{\mathrm{f}}}{m_{\mathrm{f}}^{*} H}+k_{1} \frac{C_{\mathrm{d}}}{m_{\mathrm{f}}^{*}}-k_{2} C_{\mathrm{f}} \frac{m_{\mathrm{f}}}{m_{\mathrm{f}}^{*}} .
$$

The $*$ means that such concentrations must be the calculated at each new time step. This is due to the fact that, since these particles are released to the river by the fertilizer complex, there will not be a steady distribution 
(as happened with natural suspended particles), and $m_{\mathrm{f}}$ will be different for each time step and for each grid cell. The second term is the transfer of radionuclides to sediments by deposition, and the third is the transfer from water to particles released by the complex; thus, $k_{1}$ is given by eqn (4) but substituting $m$ by $m_{\mathrm{f}}$. The last term is the transfer of radionuclides from particles to water.

The specific activity in the total suspended matter, $C_{\mathrm{t}}$, which includes both kinds of particles is:

$$
C_{\mathrm{t}}=\frac{m C_{\mathrm{s}}+m_{\mathrm{f}} C_{\mathrm{f}}}{m+m_{\mathrm{f}}}
$$

The equation that gives the time evolution of specific activity in the active sediment is:

$$
\frac{\partial a_{\mathrm{s}}}{\partial t}=k_{1} \frac{H C_{\mathrm{d}}}{L \rho_{\mathrm{m}} f} \times 10^{-3}-k_{2} \psi a_{\mathrm{s}}+\left(\frac{w C_{\mathrm{s}}}{L f \rho_{\mathrm{m}}}+\frac{w_{\mathrm{f}} C_{\mathrm{f}}}{L f \rho_{\mathrm{m}}}\right)
$$

The first term is the transfer of radionuclides from water to the sediment, and thus, $k_{1}$ is given by:

$$
k_{1}=\chi_{1} \frac{3 L f \psi}{R H}
$$

The second term is the transfer of radionuclides from the sediment to water, and the last term is the transfer from both types of suspended particles to the sediment as a result of deposition processes.

\section{Transfer of radionuclides to soils and plants}

As discussed above, the incorporation of radionuclides in soils in the marsh area takes place by the same processes by which they are incorporated into bottom sediments. Thus, the equation that gives the time evolution of specific activity in the soil is similar to eqn (7). There are, however, some differences. It is assumed that soils are flooded during half the tidal cycle. Thus, the 'effective' time step in which the transfers of radionuclides take place is half the real time step. The tidal amplitude in the Odiel river in a medium tide situation is $1 \mathrm{~m}$. Thus, the mean height of water above the soil is, after averaging a sine function over the first half cycle, $0.3 \mathrm{~m}$. It is also assumed that, when the soil is flooded, the concentration of radionuclides and particles in the water that cover such soil is the mean value of concentrations in the water compartments that surround the soil compartment. Finally, sedimentation rates in the soils are corrected to take into account the different height of the water 
column, since deposition depends inversely on water depth (Periáñez et al., $1996 c$ ).

Of course, these assumptions may lead to inaccuracies of the model since, for instance, not all the soils will be flooded during half the tidal cycle. However, the model gives, as will be seen, a good estimate of the general activity levels in the marsh.

The concentration ratio, $C_{\mathrm{R}}$, for a plant is defined as:

$$
C_{\mathrm{R}}=\frac{C_{\mathrm{p}}}{C_{\text {soil }}}
$$

where specific activities in the plant, $C_{p}$, and in the soil, $C_{\text {soil }}$, are expressed in the same units.

$A_{\mathrm{p}}$ is defined as the total activity in the plants in a given compartment and $A_{\mathrm{s}}$ as the total activity in the soil in such a compartment. Let $N$ be the activity exchanged between the soil and the plants during the time step $\Delta t$. From the definition of $C_{\mathrm{R}}$ :

$$
\frac{A_{\mathrm{p}}+N}{M_{\mathrm{p}}}=\frac{A_{\mathrm{s}}-N}{M_{\mathrm{s}}} C_{\mathrm{R}},
$$

where $M_{\mathrm{p}}$ and $M_{\mathrm{s}}$ are the total mass of plants and soil, respectively, in the compartment. From this equation, we obtain:

$N=\frac{A_{\mathrm{s}} C_{\mathrm{R}} M_{\mathrm{p}}-A_{\mathrm{p}} M_{\mathrm{s}}}{M_{\mathrm{s}}+C_{\mathrm{R}} M_{\mathrm{p}}}$.

Thus, specific activities in the plants and soils, $C_{\mathrm{p}}^{*}$ and $C_{\text {soil }}^{*}$, after each time step, are, respectively:

$$
C_{\mathrm{p}}^{*}=C_{\mathrm{p}}+\frac{N}{M_{\mathrm{p}}}=C_{\mathrm{p}}+\frac{C_{\mathrm{R}} C_{\text {soil }}-C_{\mathrm{p}}}{1+C_{\mathrm{R}} M_{\mathrm{p}} / M_{\mathrm{s}}}
$$

and

$$
C_{\text {soil }}^{*}=C_{\text {soil }}-\frac{N}{M_{\mathrm{s}}}=C_{\text {soil }}-\frac{C_{\mathrm{R}} C_{\text {soil }}-C_{\mathrm{p}}}{C_{\mathrm{R}}+M_{\mathrm{s}} / M_{\mathrm{p}}} .
$$

\section{Computational scheme}

A code to solve the equations involved in our model was implemented on a VAX/VMS computer. The residual water velocity field was calculated and kept in a file, which was used as input data. A preliminary code, which included only the suspended matter (natural particles) equation, was run to obtain the steady state suspended matter distribution and 
sedimentation rates, which were also kept in a data file. Then, the code that includes all the processes can be run. The equations for the dissolved phase, both kinds of suspended matter and bottom sediments are solved for each time step and for each grid cell. If a given compartment is not a water compartment but a marsh compartment, the code jumps to a subroutine that computes activities in the soil and plants. The output provides detailed information: time evolution of activities in each of the phases at desired positions of the grid, specific activity maps at desired times and specific activity profiles along selected sections of the river and marsh.

\section{MODEL RESULTS}

\section{Parameters for the model}

The boundary conditions for the advective-diffusive terms in the equations are the same as those used in Periáñez et al. (1994a). The diffusion coefficients in these terms were selected along the $x$ and $y$ axes, after a calibration exercise, as $K_{x}=25$ and $K_{y}=20 \mathrm{~m}^{2} \mathrm{~s}^{-1}$, respectively.

The mixing depth $L$ was taken as $L=0.1 \mathrm{~m}$, following previous modelling works (Abril \& García-León, 1993b; Periáñez et al., 1996b). The density of suspended matter particles is taken as $\rho=2600 \mathrm{~kg} \mathrm{~m}^{-3}$, which is the established value for soil particles density (Baver et al., 1972) and has been used in Periáñez et al. (1996b). A step function was adopted, as a first approach, for the size distribution of such particles. Thus, thcir mcan radius is taken as $R=15 \mu \mathrm{m}$ (Periáñez et al., 1996b) since only particles with diameter $\phi<62.5 \mu \mathrm{m}$ can be present in the water column as suspended matter (Gurbutt et al., 1987).

The bulk density of the sediments and the parameter $f$ were measured at several points of the estuary (Universidad de Sevilla, 1991). In this work, we used the averaged values $f=0.3$ and $\rho_{\mathrm{m}}=700 \mathrm{~kg} \mathrm{~m}^{-3}$.

The geometrical accessibility factor was selected, after a calibration exercise, as $\psi=0.001$. Water depths were obtained from marine charts.

The model was run for ${ }^{238} \mathrm{U},{ }^{232} \mathrm{Th}$ and ${ }^{210} \mathrm{Po}$. Thus, the exchange velocity $\chi_{1}$ and the transfer coefficient $k_{2}$ must be known for these radionuclides. Kinetic transfer coefficients have been measured for a wide set of elements (Nyffeler et al., 1984) by laboratory experiments. They showed that there is a very small variation in $k_{2}$ for all these elements (less than an order of magnitude). This small variation opens the possibility (Nyffeler et al., 1984) of estimating $\chi_{1}$ without the need for laboratory experiments. 
The $k_{2}$ of ${ }^{226} \mathrm{Ra}$ was measured for the Odiel estuary from laboratory experiments (Periáñez, 1995). Thus, the $\chi_{1}$ for $U, T h$ and Po can be calculated from the $k_{\mathrm{d}}$ in the Odiel estuary, of U, Th, and Po and the $k_{2}$ of ${ }^{226} \mathrm{Ra}$ since a relationship between $k_{\mathrm{d}}, \chi_{1}$ and $k_{2}$ exists (Periáñez et al., 1996b). From the laboratory experiments (Periáñez, 1995), $k_{2}=8.17 \times 10^{-6} \mathrm{~s}^{-1}$. Then for $\mathrm{U} \chi_{1}=1.06 \times 10^{-7} \mathrm{~m} \mathrm{~s}^{-1}$, for $\mathrm{Th}$ $\chi_{1}=1.46 \times 10^{-6} \mathrm{~m} \mathrm{~s}^{-1}$ and for Po $\chi_{1}=3.0 \times 10^{-6} \mathrm{~m} \mathrm{~s}^{-1}$. The $k_{\mathrm{d}}$ values of $\mathrm{U}$ and $\mathrm{Th}$ in the Odiel estuary are obtained from Periáñez et al.(1996d), and, in the case of Po, from Martínez-Aguirre and García-León (1996a). The exchange velocities, calculated in this way, have yielded good results in previous modelling work concerning $\mathrm{U}$ and $\mathrm{Th}$ in the Odiel estuary (Periáñez \& Martínez-Aguirre, in press).

The plant included in our model was Spartina densiflora. The $C_{\mathrm{R}}$ values for this plant in the Odiel march are obtained from experimental measurements. $C_{\mathrm{R}}$ is, generally, not linearly related to the specific activity in the soil. Indeed, in Martínez-Aguirre and García-León (1996b) and in Martínez-Aguirre $e t$ al. (in press) it can be seen that, for radionuclides from the ${ }^{238} \mathrm{U}$ decay chain, the relationship between the $C_{\mathrm{R}}$ and the specific activity in the substrate soil seems to be hyperbolic. Thus, for ${ }^{238} \mathrm{U}$ :

$$
C_{\mathrm{R}}=0.343 C_{\mathrm{soil}}^{-0.374} \text {, }
$$

and for ${ }^{210} \mathrm{Po}$ :

$$
C_{\mathrm{R}}=2.456 C_{\text {soil }}^{-0.663} \text {. }
$$

In the case of ${ }^{232} \mathrm{Th}$, however, the $C_{\mathrm{R}}$ seems to be constant, independent of the specific activity in the soil. The mean value of the ${ }^{232} \mathrm{Th} C_{\mathrm{R}}$ is (Martínez-Aguirre et al., in press):

$$
C_{\mathrm{R}}=0.036 \pm 0.018 \text {. }
$$

In all cases, specific activity in the soil, $C_{\text {soil }}$ is given in $\mathrm{mBq} \mathrm{g}^{-1}$.

Finally, it is necessary to know the ratio plant mass per soil mass, $M_{\mathrm{p}} / M_{\mathrm{s}}$, in the marsh compartments. It seems clear that this parameter must be very small. Thus, we have assumed that $M_{\mathrm{p}} / M_{\mathrm{s}}=10^{-5}$ since good results can be obtained with this value.

It should be pointed out that the equations that give the $C_{\mathrm{R}}$ for the relevant radionuclides are the best numerical fits for a large number of samples (Martinez-Aguirre et al., in press). Thus, for a given plant sample, the experimental $C_{\mathrm{R}}$ can differ by up to a factor 2 from the value predicted by the corresponding equation. This means that the model results for plants should be evaluated in terms of general levels of specific activities, that is, we must consider whether the model gives the general behaviour 
and distribution of radionuclides in the plants collected along the estuary and whether the model gives a good estimate of the mean levels of specific activities in the plants.

\section{Results}

In Fig. 3, a map of the modelled area is shown. In the map, the points where sediment, soil and plant samples were collected are shown. Concentrations of ${ }^{238} \mathrm{U},{ }^{232} \mathrm{Th}$ and ${ }^{210} \mathrm{Po}$ in such samples, which were collected in November 1993, were determined, and the results can be seen in Martínez-Aguirre and García-León $(1996 b, 1997)$ and MartínezAguirre et al. (in press, 1996b).

The source of radionuclides to the river (the point where the fertilizer complex releases its wastes) is located in compartment $(9,29)$ (see Fig. 3). The magnitude of the source term is not known. Thus, the source term magnitude was changed, by trial and error, until the model reproduced the experimental data. Experimental results represent the mean, averaged over 30 years, accumulation of radionuclides in soils and plants growing in such soils. Thus, we use a mean source term that is constant in time. This, together with a mean suspended matter distribution and a residual (averaged) water circulation, produces a mean distribution of radionuclides in soils and plants.

As an example, in Fig. 4 the computed distribution of ${ }^{238} U$ along the estuary in water and bottom sediments is shown. As can be seen [Fig. 4(b)], the largest concentrations in the sediments appear around and downstream of the source. This is due to the fact that contaminated particles, relcased from the source, arc quickly deposited on the river bed. This is in agreement with previous experimental results (Martínez-Aguirre et al., 1995).

The magnitude of the source term in the case of ${ }^{238} \mathrm{U}$ was taken as $6.7 \times 10^{6} \mathrm{~Bq}$ per time step for both dissolved and particulate radionuclides. This gives an annual input of $7.0 \times 10^{11} \mathrm{~Bq}$ year $^{-1}$. This number is in agreement, within an order of magnitude, with the $3.0 \times 10^{11} \mathrm{~Bq} \mathrm{year}^{-1}$ which are estimated to be discharged in an estuary in the Netherlands (Van der Heijde et al., 1988) from a fertilizer complex. Experimental and computed ${ }^{238} \mathrm{U}$ concentrations in soils and plants along the estuary are shown in Figs 5(A) and 5(B), respectively. There, the $x$ axis gives the position in the grid (compartment number) measured from south to north. Thus, the lines are specific activity profiles along a section of the river, which follows the points where samples were collected. As can be seen in Fig. 5, the general activity levels in soils and plants are reproduced by the model. Experimental and model results are, however, different for some 


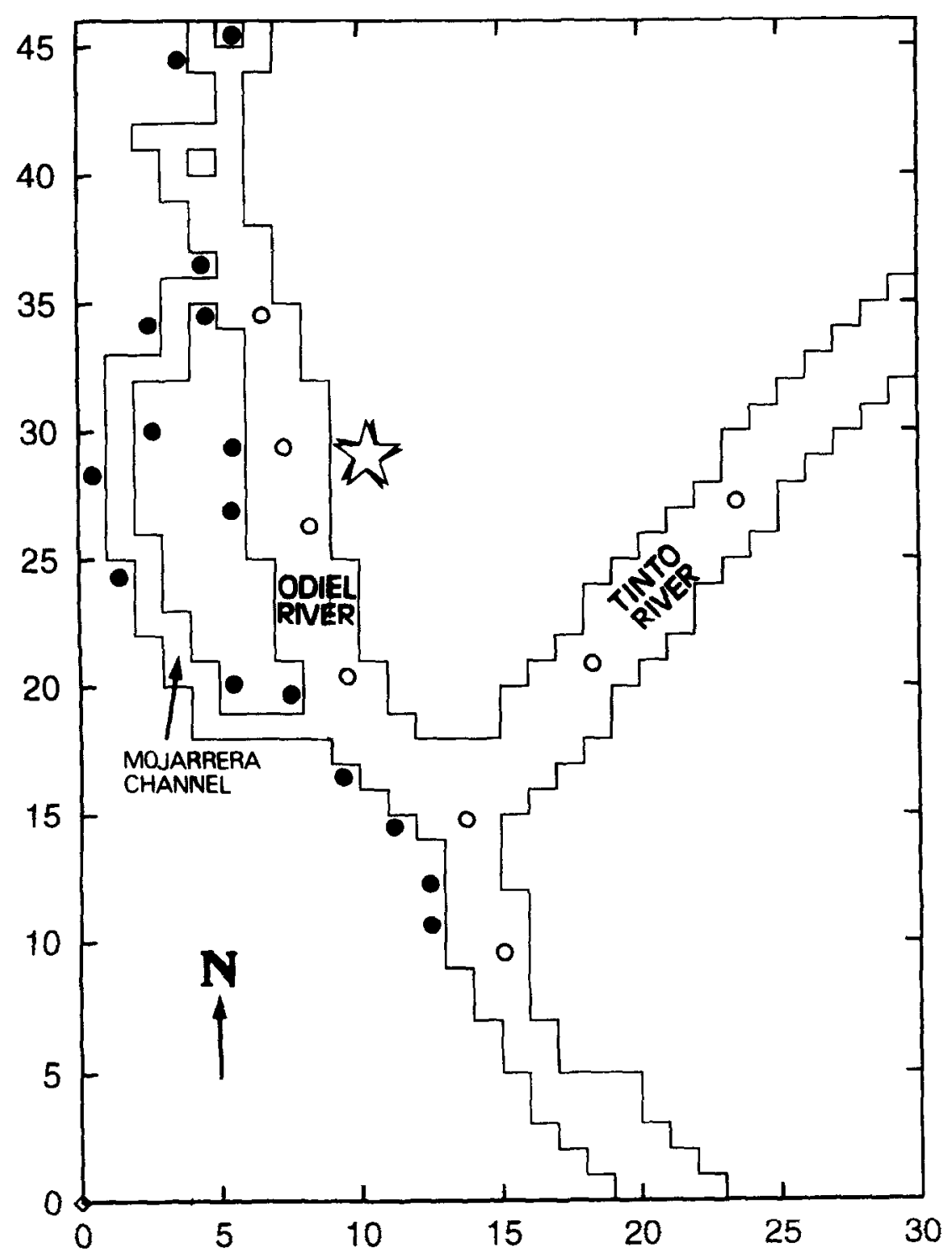

Fig. 3. Map of the modelled area showing the fertilizer complex (star), the points where bottom sediments were collected (open circles) and the points in the marsh where soil and plant samples were collected (solid circles).

samples. This may be an effect of taking mean parameters in the model: for some points, the soil density and the parameter $f$ (for instance) may be different from the mean if there is a large percentage of sand. This is the case with samples whose $x$ coordinates in Fig. 5 are 13 and 16 (MartinezAguirre $e t$ al., in press). On the other hand, it was assumed that soils were 


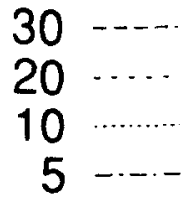

A

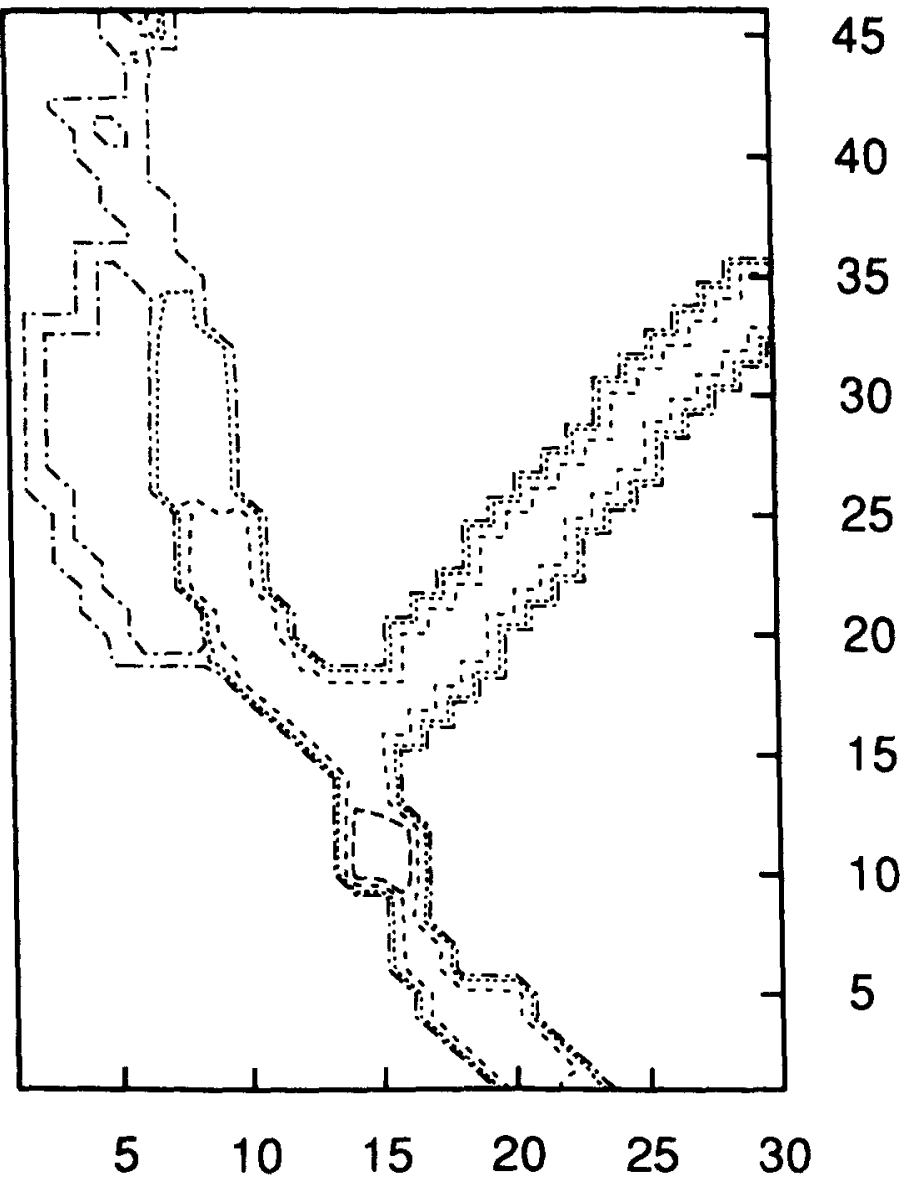

Fig. 4. Distribution of ${ }^{238} \mathrm{U}$ in the modelled area. (A) Water $\left(\mathrm{mBq}^{-1}\right)$.

flooded during half the tidal cycle: some soils will be under the water for almost the whole tidal cycle, while other soils will be flooded just during spring tide situations. Due to these considerations, we must compare the model and experimental results in terms of 'general levels' of activity.

In the case of ${ }^{210} \mathrm{Po}$, the magnitude of the source terms was $2.0 \times 10^{6}$ and $4.0 \times 10^{6} \mathrm{~Bq}$ per time step for dissolved and particulate radio- 


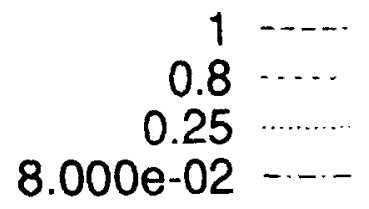

B

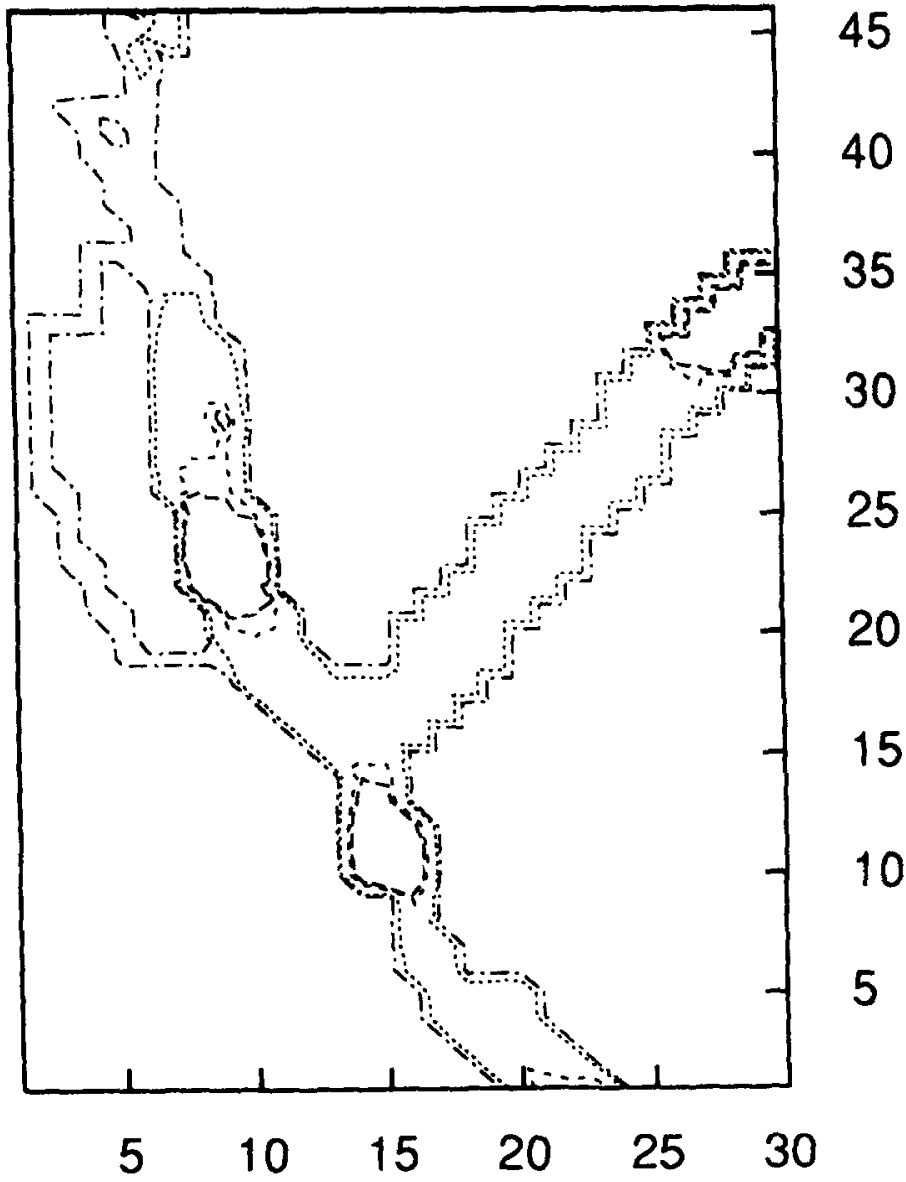

Fig. 4. contd. (B) Bottom sediments $\left(\mathrm{Bq}^{-1}\right)$.

nuclides, respectively. These input rates lead to an annual discharge of $3.2 \times 10^{11} \mathrm{~Bq}$ year $^{-1}$. In the Netherlands, it was estimated (Van der Heijde et al., 1988) that $1.6 \times 10^{12} \mathrm{~Bq}$ of ${ }^{210} \mathrm{Po}$ are annually discharged to an estuary from a fertilizer complex, a result that is similar to our estimate. Experimental and computed ${ }^{210}$ Po concentrations in soils and plants are shown in Figs 6(A) and 6(B), respectively. Again, the general 

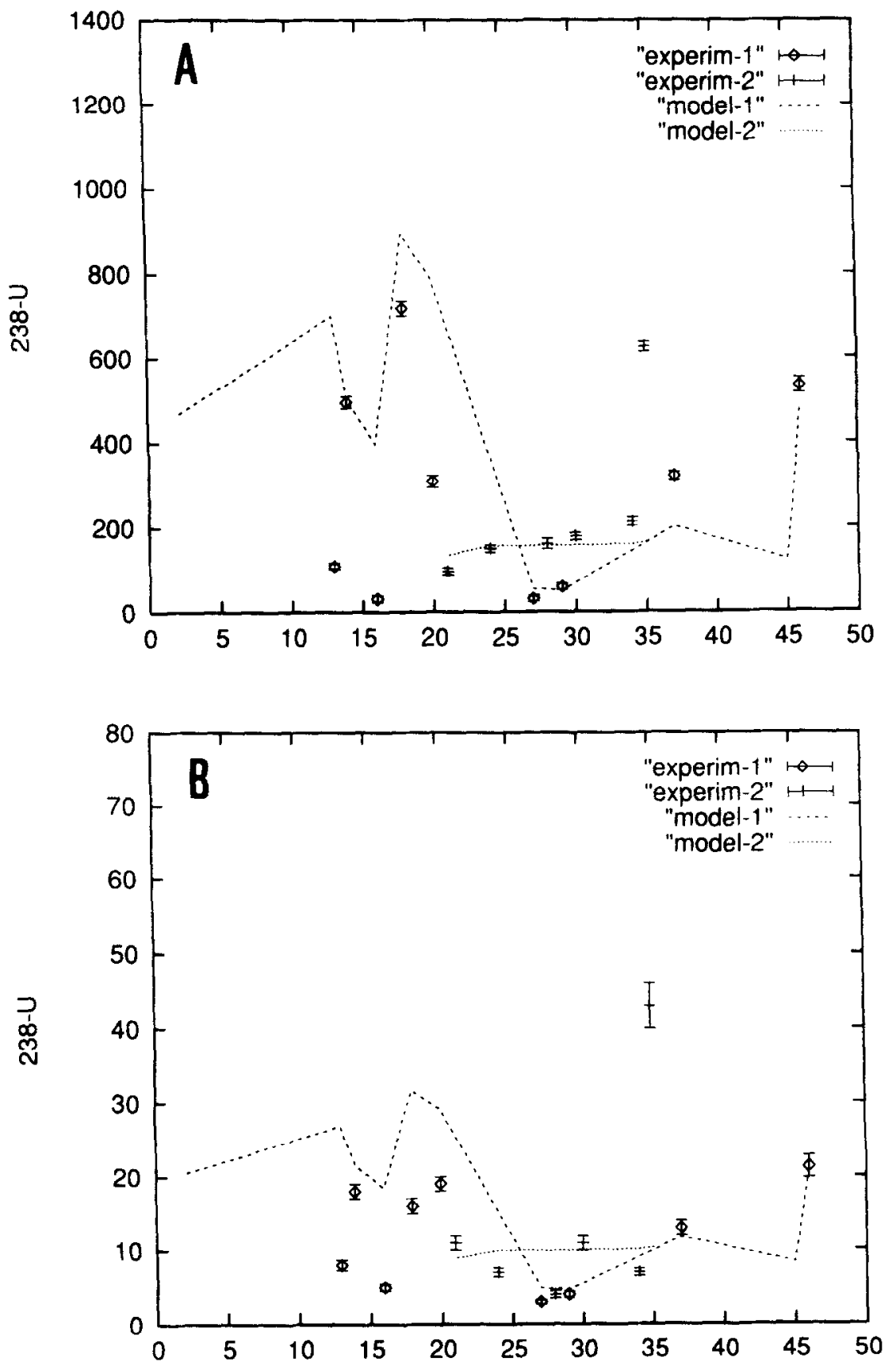

Fig. 5. Experimental (points) and computed (lines) ${ }^{238} \mathrm{U}$ specific activities ( $\mathrm{mBq}^{-1}$ ) in soils (A) and plants (B). The $x$ axis represents the position in the grid. 1 represents samples collected from the Odiel river and 2 samples collected from the Mojarrera channel (see Fig. 3). 
activity levels are well reproduced by the model. Lead-210 concentrations were also measured in some bottom sediments collected (see Fig. 3) from the Odiel and Tinto rivers (Martínez-Aguirre et al., 1996). Experimental and model results for these bottom sediments are shown in Fig. 7. There, the $x$ axis gives the position in the grid from west to east, and the line is an activity profile following the points where sediments were collected. As can be seen, the model results are in good agreement with the experimental results. This demonstrates that the processes of transfer of radionuclides to the solid phase are well described in the model. The difference between experimental and model results that appears for some soil and plant samples is due to the difficulty of including soils in the model (not all the soils are under the water during the same time, and not all the soils have the same fraction of active, $\phi<62.5 \mu \mathrm{m}$, particles).

The results for ${ }^{232} \mathrm{Th}$ are shown in Figs $8(\mathrm{~A})$ (soils) and $8(\mathrm{~B})$ (plants). The magnitude of the source term for this radionuclide is $3.3 \times 10^{5} \mathrm{~Bq}$ per time step for dissolved and particulate radionuclides. This input implies an annual discharge rate of $3.7 \times 10^{10} \mathrm{~Bq}_{\text {year }}{ }^{-1}$, which is of the same order of magnitude than the estimate for the estuary in the Netherlands: $1.8 \times 10^{10} \mathrm{~Bq} \mathrm{year}^{-1}$ (Van der Heijde et al., 1988). As can be seen in Fig. 8, the general behaviour of ${ }^{232} \mathrm{Th}$ is reproduced by the model.

In general, activity levels in soils from the Mojarrera channel are very well reproduced by the model for the three studied radionuclides. The general distribution of radionuclides along the Odiel river soils and sediments is also given by the model. The largest differences between the model predictions and the experimental results appear in the case of plants. Such differences may be due to the use of $C_{\mathrm{K}}$, as discussed in 'Parameters for the model'. Of course, if for a given soil sample, model and experimental results do not agree very well (the reason has been discussed above), this will be an additional source of error for the model results corresponding to the plants growing in such soil.

Some predictive studies concerning the process of cleaning the marsh have been carried out. If, at a given instant of time, the discharge of radionuclides to the river stops, the water will progressively wash the sediments and soils. Consequently, plants growing in such soils will have a smaller specific activity than plants that grow before the input of radionuclides has ceased. Thus, after a period of time, plants would grow with background levels of activity. The question is: how long does it take? A numerical experiment has been carried out for ${ }^{210} \mathrm{Po}$, whose results are shown in Figs 9 and 10. The source terms for this radionuclide has been amplified in such a way that present activity levels in soils, plants and sediments are reached in 

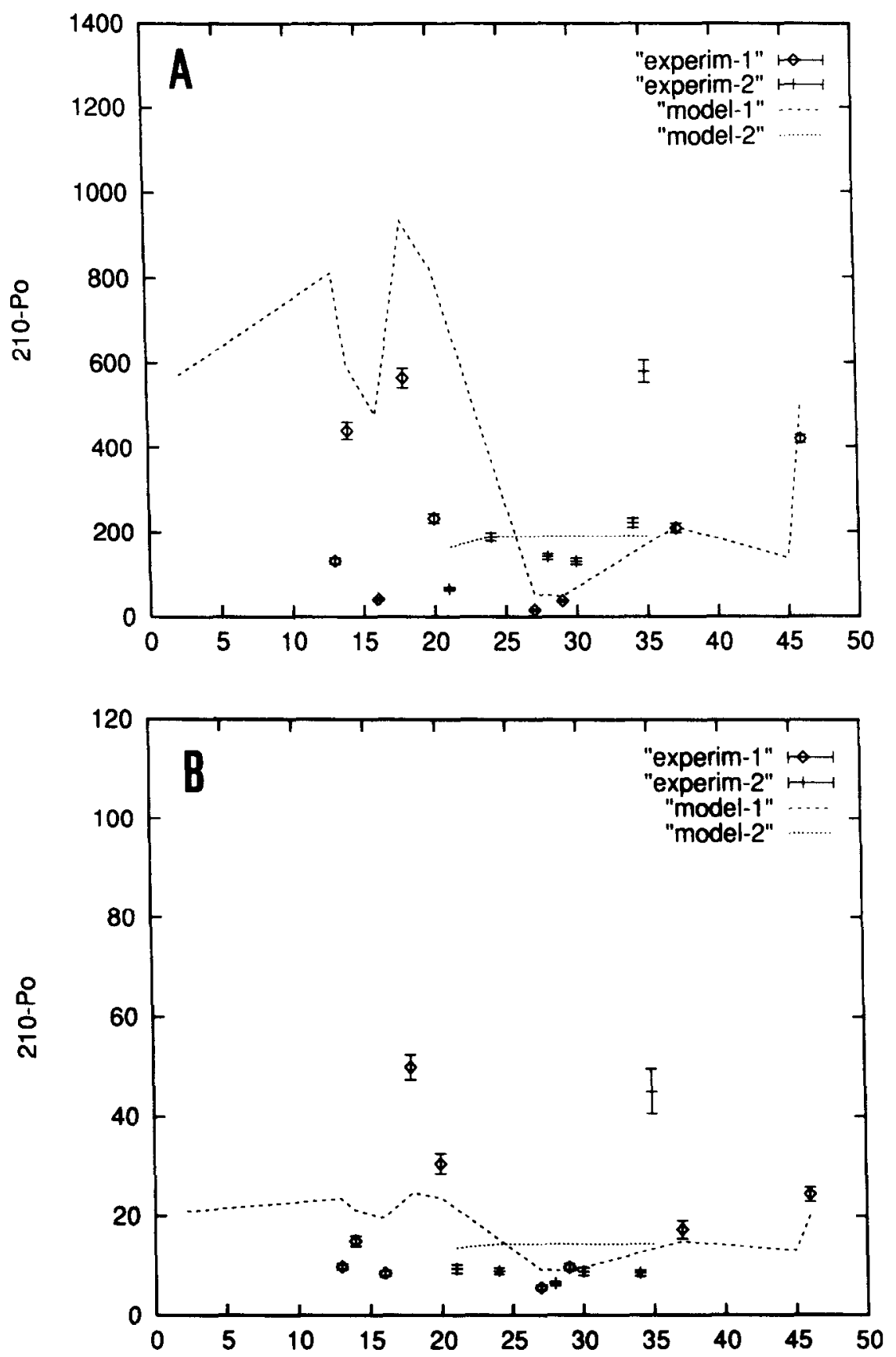

Fig. 6. Same as Fig. 5, but for ${ }^{210} \mathrm{Po}$. 


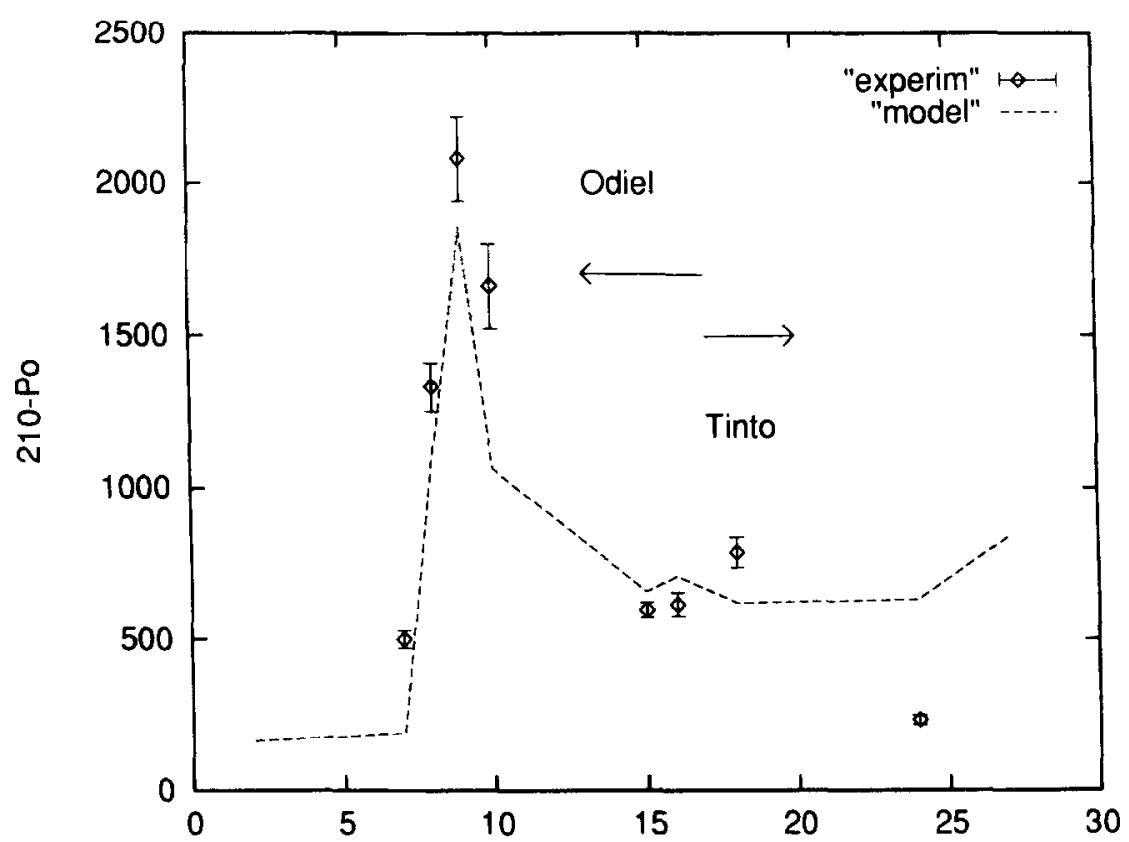

Fig. 7. Experimental (points) and computed (line) ${ }^{210} \mathrm{Po}$ specific activity $\left(\mathrm{mBq}^{-1}\right.$ ) in bottom sediments collected from the Odiel and Tinto river. The $x$ axis is the position in the grid.

a year of simulation. Then, the discharge from the source stops and the simulation continues until 15 years have elapsed. The time evolution of ${ }^{210}$ Po specific activity in four locations has been studied: bottom sediments from a point in the Odiel river upstream of the source, the point where the source is located, a point in the Tinto river and a soil in the Mojarrera channel. Such time evolutions are shown in Fig. 9. After 14 years, the specific activity has decreased by $30 \%$ in the point upstream the source and in the Tinto river, by $42 \%$ in the soil of the Mojarrera channel and by $47 \%$ in the source. It is not surprising that the more contaminated point is cleaned faster, since the rate at which radionuclides are exchanged from the sediment to the water is proportional to the specific activity in the sediment [see eqn (7)]. The Mojarrera channel is also cleaned faster than the Odiel and Tinto rivers. This could be due to the fact that water in the channel is less contaminated than in both rivers [see Fig. 4(A)].

Plants growing in consecutive years will have smaller specific activities, since the activity in the soil is decreasing. In Fig. 10, the specific activity of plants growing in soils of the Mojarrera channel for each of the 15 years of simulation is shown. The points are the model results and represent the specific activity of a plant that grows in a given year after the 

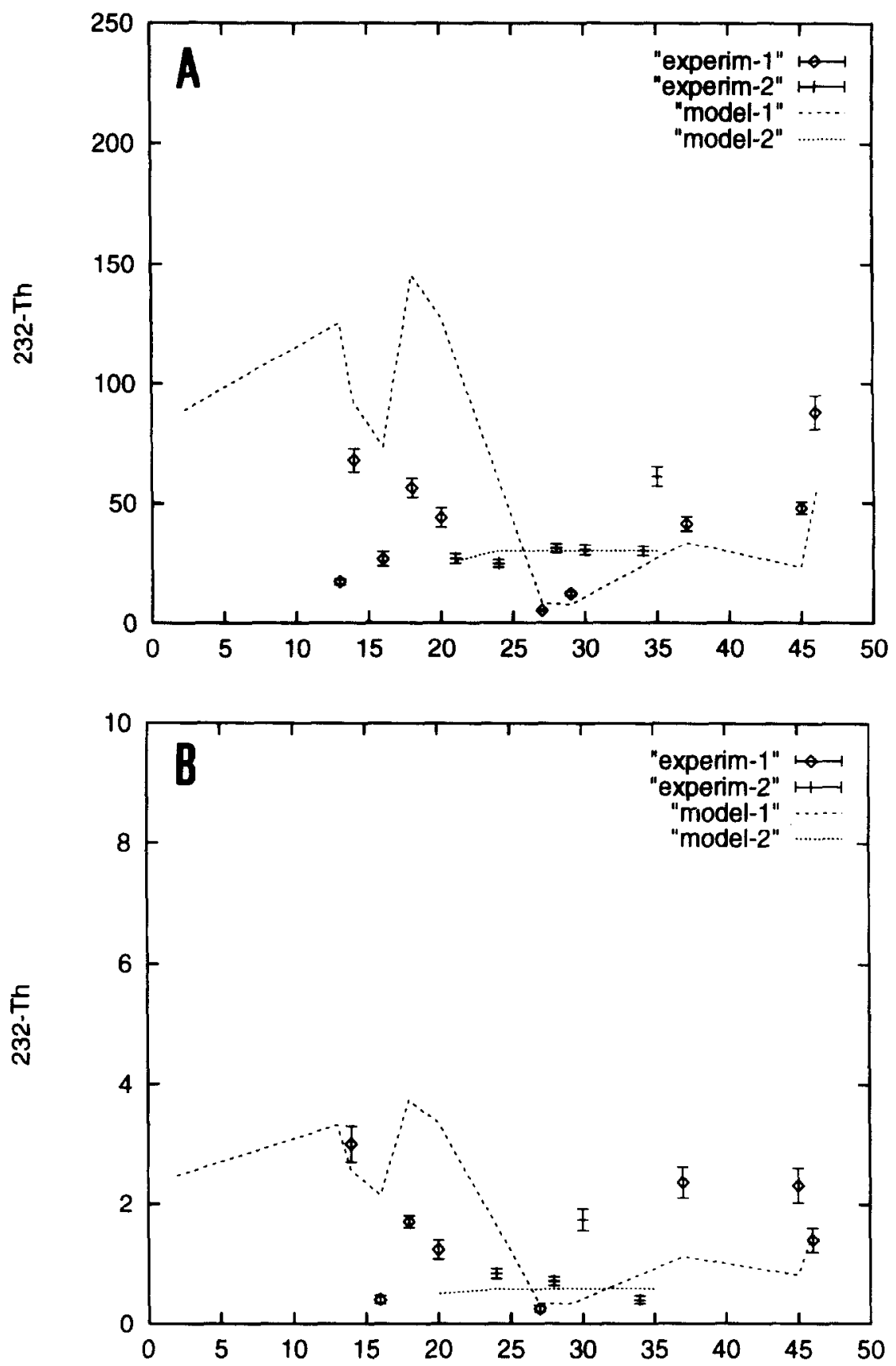

Fig. 8. Same as Fig. 5, but for ${ }^{232}$ Th. 


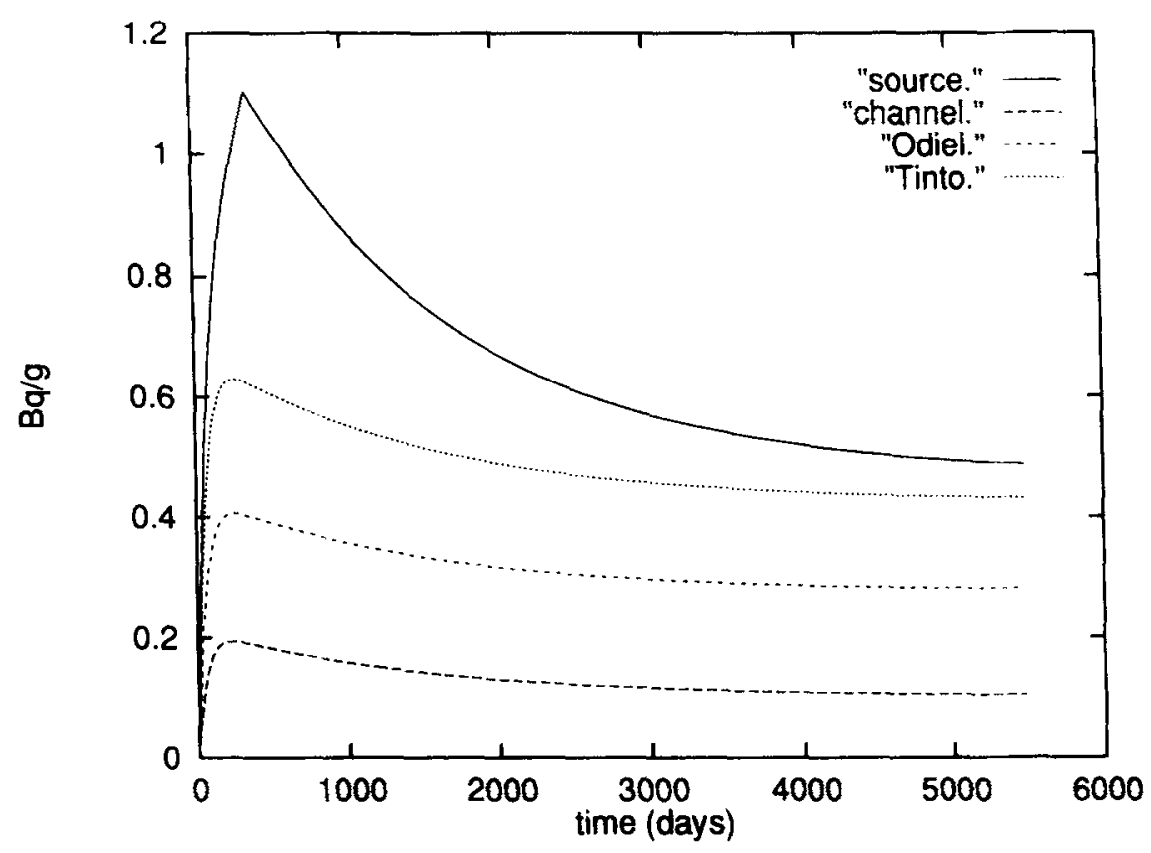

Fig. 9. Time evolution of ${ }^{210} \mathrm{Po}$ specific activity $\left(\mathrm{Bq} \mathrm{g}^{-1}\right)$ in four points of the modelled area (see text) over 15 years.

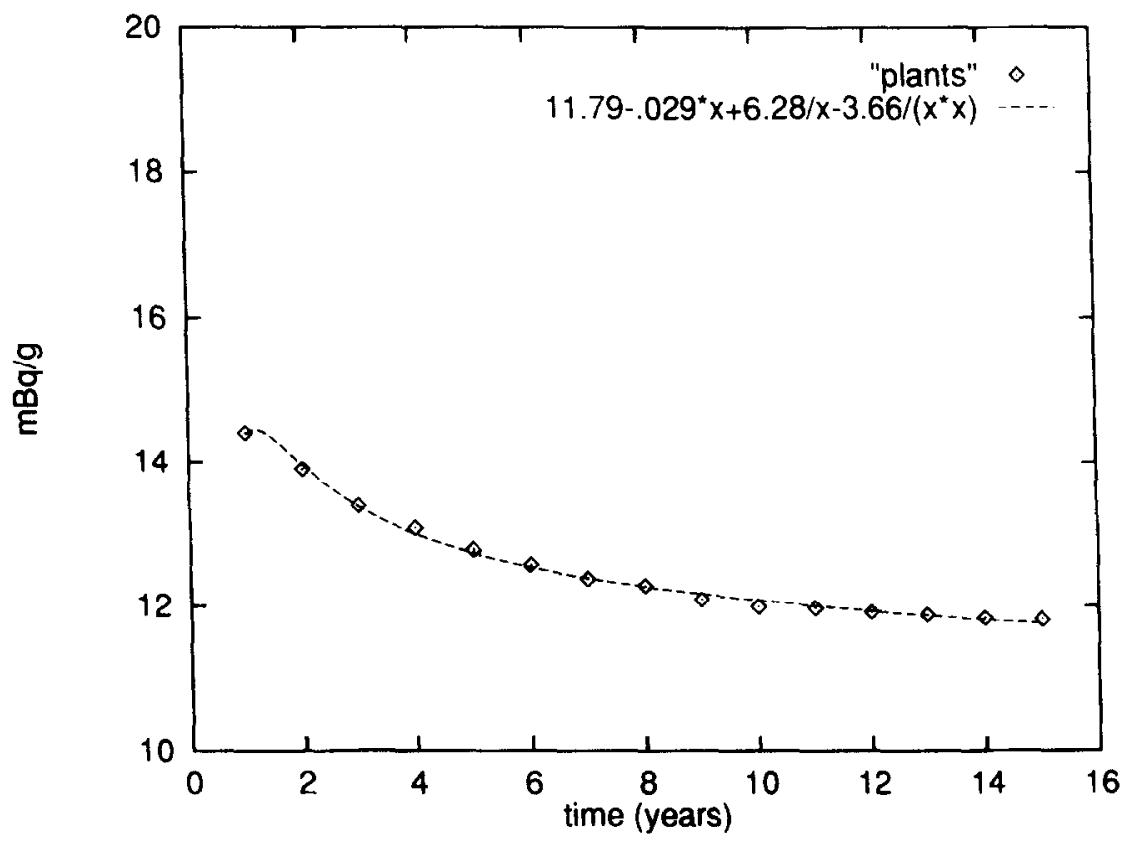

Fig. 10. ${ }^{210} \mathrm{Po}$ specific activity $\left(\mathrm{mBq} \mathrm{g}^{-1}\right)$ in plants that grow in each year (points). The line is the function given in the figure. 
discharges have ceased (in year 1). The line is a numerical fit to the data presented in Fig. 10. From this function can be estimated the time that should elapse until plants grow with background levels of activity. In Martínez-Aguirre et al. (in press), it can be seen that ${ }^{210}$ Po specific activity in plants not affected by the fertilizer complex (since they are far enough from it) is around $10 \mathrm{mBq} \mathrm{g}^{-1}$. The time needed to reach this level is (from the function in Fig. 10) 65 years. This is an estimate of the time that the process of cleaning of the marsh would take. Nevertheless, this process can be accelerated by extreme conditions, such as heavy rains, strong winds (which increase water current) and spring tides, since the model has been developed for medium tides, and the effect of rains and winds is not included.

\section{CONCLUSIONS}

A mathematical model to simulate the dispersion of non-conservative radionuclides in an estuarine system, including the ionic exchanges of radionuclides between water and the solid phases (bottom sediments and two kinds of suspended particles) as well as the transfer of radionuclides to soils and plants has been developed. Ionic exchanges of radionuclides are formulated in terms of kinetic transfer coefficients and the transfer to plants in terms of the concentration ratios $C_{\mathrm{R}}$.

Since the model must run for long time scales, the residual water circulation has been used to solve the advective-diffusive terms in the dispersion equations of radionuclides and to obtain the steady distribution of suspended matter and mean sedimentation rates.

The model has been applied to the Odiel estuary, which surrounds a marsh area. The parameters involved in the model have been obtained from experimental measurements and from calibration exercises. A phosphate fertilizer-processing plant releases its wastes to the Odiel river, wastes that contain large amounts of $\mathrm{U}, \mathrm{Th}, \mathrm{Ra}$ and their daughters. The model gives good results in predicting the general behaviour and activity levels of ${ }^{238} \mathrm{U}$, ${ }^{210} \mathrm{Po}$ and ${ }^{232} \mathrm{Th}$ in soils, sediments and plants collected from the river and from the marsh area. Thus, the water dynamics of the estuary is responsible for the observed distribution pattern of radionuclides in the estuary and marsh. It also seems clear that the enhanced activity levels measured in the marsh are due to the operation of the fertilizer complex.

A predictive study concerning the process of cleaning of the marsh has also been carried out. This study has revealed that about 65 years must elapse (if activity discharges stop at a given time) so that plants can grow with background levels of activity. 


\section{ACKNOWLEDGEMENT}

This work was partially supported by the EU Contract F13P-CT92-0035 and ENRESA.

\section{REFERENCES}

Abril, J. M. \& García-León, M. (1993a). A 2D 4-phases marine dispersion model for radionuclides. Part 1: Conceptual and computational model. J. Environ. Radioactivity, 20, 71-88.

Abril, J. M. \& García-León, M. (1993b). A 2D 4-phases marine dispersion model for radionuclides. Part 2: Two applications. J. Environ. Radioactivity, 20, 89 115.

Baver, L. D., Gardner, W. H. \& Gardner, W. R. (1972). Soil Physics. John Wiley, New York.

Benes, P., Cernik, M. \& Slavik, O. (1994). Modelling of the migration of ${ }^{137} \mathrm{Cs}$ accidentally released into a small river. J. Environ. Radioactivity, 22, 27993.

Elliott, A. J., Dale, A. C. \& Proctor, R. (1992). Modelling the movement of pollutants in the UK shelf seas. Mar. Pollut. Bull., 24, 614-9.

Gurbutt, P. A., Kershaw, P. J. \& Durance, J. A. (1987). Modelling the distribution of soluble and particle adsorbed radionuclides in the Irish sea. In Radionuclides. A Tool for Oceanography, eds J. C. Guary, P. Guegueniat \& R. J. Pentreath. Elsevier, Oxford, pp. 395-490.

Howorth, J. M. \& Eggleton, A. E. J. (1988). Modelling the sea to land transfer of marine discharges from Sellafield. Validation against environmental measurements. In Reliability of Radioactive Transfer Models, ed. G. Desmet. Elsevier, Oxford, pp. 261-7.

Kershaw, P. J., Pentreath, R. H., Gurbutt, P. A., Woodhead, D. S., Durance, J. A. \& Camplin, W. C. (1988). Modelling the behaviour of long-lived radionuclides in the Irish sea. Comparison of model predictions with field observations. In Reliability of Radioactive Transfer Models, ed. G. Desmet. Elsevier, Oxford, pp. 241-9.

Laiche, T. P. \& Scott, L. M. (1991). A radiological evaluation of phosphogypsum. Hlth Phys., 60, 691-3.

Martinez-Aguirre, A. \& García-León, M. $(1996 a) .{ }^{210} \mathrm{~Pb}$ distribution in riverwaters and sediments near phosphate fertilizer factories. Appl. Radiat. Isot., 47, 599-602.

Martínez-Aguirre, A. \& García-León, M. (1997). Radioactive impact of the phosphate fertilizer ore processing in a wet marshland in southwestern Spain. J. Environ. Radioactivity, 34, 45-57.

Martínez-Aguirre, A. \& García-León, M. (1996b). Transfer of natural radionuclides from soils to plants in a wet marshland. Appl. Radiat. Isot, 47, 11038.

Martínez-Aguirre, A., García-León, M. \& Ivanovich, M. (1994a). U and Th distribution in solution and suspended matter from rivers affected by phosphate rock processing in southwestern Spain. Nucl. Instrum. Meths, A339, 287-93. 
Martínez-Aguirre, A., García-León, M. \& Ivanovich, M. (1994b). The distribution of $\mathrm{U}, \mathrm{Th}$ and ${ }^{226} \mathrm{Ra}$ derived from the phosphate fertilizer industries on an estuarine system in southwest Spain. J. Environ. Radioactivity, 22, $155-77$.

Martínez-Aguirre, A., García-León, M. \& Ivanovich, M. (1995). U and Th speciation in river sediments. Sci. Tot. Environment, 173/174, $203-9$.

Martínez-Aguirre, A., García-Orellana, I. \& García-León, M. (in press). Transfer on natural radionuclides from soils to plants in a marsh enhanced by the operation on non-nuclear industries. $J$. Environ. Radioactivity.

Martínez-Aguirre, A., Garcia-León, M., Gascó, C. \& Travesí, A. (1996). Antropogenic emissions of ${ }^{210} \mathrm{Po},{ }^{210} \mathrm{~Pb}$ and ${ }^{226} \mathrm{Ra}$ in an estuarine environment. $J$. Radioanal. Nucl. Chem. Articles, 207, 357-67.

Nyffeler, U. P., Li, Y. H. \& Santschi, P. H. (1984). A kinetic approach to describe trace-element distribution between particles and solution in natural aquatic systems. Geochim. Cosmochim. Acta, 48, 1513-22.

Periáñez, R. (1995). Un modelo matemático para la simulación de la dispersion de radionúclidos no conservativos en un sistema estuario. Aplicación a la ría de Huelva. Ph.D. Thesis, Universidad de Sevilla (in Spanish).

Periáñez, R., Abril, J. M. \& Garcia-León, M. (1996a). Modelling the dispersion of non-conservative radionuclides in tidal waters. Part 1: conceptual and mathematical model. J. Environ. Radioactivity, 31, 127-41.

Periáñez, R., Abril, J. M. \& García-León, M. (1996b). Modelling the dispersion of non-conservative radionuclides in tidal waters. Part 2: Application to ${ }^{226} \mathrm{Ra}$ dispersion in an estuarine system. J. Environ. Radioactivity, 31, 253-72.

Periáñez, R., Abril, J. M. \& García-León, M. (1996c). Modelling the suspended matter distribution in an estuarine system. Application to the Odiel river in southwest Spain. Ecol. Modelling, 87, 169-79.

Periáñez, R. \& García-León, M. (1993). Ra-isotopes around a phosphate fertilizer complex in an estuarine system in the southwest of Spain. $J$. Radioanal. Nucl. Chem. Articles, 172, 71-9.

Periáñez, R., Abril, J. M. \& García-León, M. (1994a). A modelling study of ${ }^{276} \mathrm{Ra}$ dispersion in an estuarine system in the southwest of Spain. J. Environ. Radioactivity, 24, 159-79.

Periáñez, R., García-León, M. \& Abril, J. M. (1994b). Radium isotopes in suspended matter in an estuarine system in the southwest of Spain. J. Radioanal. Nucl. Chem. Articles, 183, 395-407.

Periáñez, R. \& Martínez-Aguirre, A. (in press). U and Th concentrations in an estuary affected by phosphate fertilizer processing: experimental results and a modelling study. J. Environ. Radioactivity.

Periáñez, R., Martínez-Aguirre, A. \& García-León, M. (1996b). U and Th isotopes in an estuarine system in southwest Spain: tidal and seasonal variations. Appl. Radiat. Isotopes, 47, 1121-5.

Prandle, D. (1974). A numerical model of the southern North sea and the river Thames. IOS $/ \mathrm{R} / 4$.

Prandle, D. (1984). A modelling study of the mixing of ${ }^{137} \mathrm{Cs}$ in the seas of the European continental shelf. Phil. Trans. R. Soc. Lond., A310, 407-36.

Prandle, D., Jago, C. F., Jones, S. E., Purdie, D. A. \& Tappin, A. (1993). The influence of horizontal circulation on the supply and distribution of tracers. Phil. Trans. R. Soc. Lond., A343, 405-21. 
Puerto Autónomo de Huelva (1989). Estudio de corrientes en la ría de Huelva, segunda fase. Technical Report produced by INTECSA (in Spanish).

Universidad de Sevilla (1991). Coeficientes de distribución de radionucleidos. Contract with ENRESA, final report (in Spanish).

Van der Heijde, H. B., Klijn, P. J. \& Passchier, W. F. (1988). Radiological impacts of the disposal of phosphogypsum. Rad. Prot. Dosim., 24, 419-23. 